\title{
Effect of organic fertilizer and microbial inoculants on soil biological properties and yield of scented rice (Oryza sativa L.)
}

\section{Amit Kumar Sah}

Department of Soil Science and Agricultural Chemistry, Bihar Agricultural University, Sabour, Bhagalpur-813210 (Bihar), INDIA

\section{Mahendra Singh*}

Department of Soil Science and Agricultural Chemistry, Bihar Agricultural University, Sabour, Bhagalpur-813210 (Bihar), INDIA

\section{Amit Kumar Pradhan}

Department of Soil Science and Agricultural Chemistry, Bihar Agricultural University, Sabour, Bhagalpur-813210 (Bihar), INDIA

\section{Sambhu Prasad}

Department of Agronomy, Bihar Agricultural University, Sabour, Bhagalpur-813210 (Bihar), INDIA

\section{N. Chatoopadhyaya}

Department of Soil Science and Agricultural Chemistry, Bihar Agricultural University, Sabour, Bhagalpur-813210 (Bihar), INDIA

\section{Subrat Keshori Behera}

Department of Statistics Mathematics and Computer application, Bihar Agricultural University, Sabour, Bhagalpur-813210 (Bihar), INDIA

\section{Kajal Kiran}

Department of Soil Science and Agricultural Chemistry, Bihar Agricultural University, Sabour, Bhagalpur-813210 (Bihar), INDIA

*Corresponding author. E-mail: m.singh30648@gmail.com

\begin{abstract}
A field experiment was conducted at Research farm of Bihar Agricultural University, Sabour with Katarni rice cv Bhagalpur Katarni during kharif season of 2017. The experiment was laid out with ten organic treatments in Randomized block design (RBD) with three replications. Results revealed that the maximum microbial population viz., Bacteria, Actinomycetes, Fungi, Azospirillum, PSB and KSB (71.66, 27.33, 57.66, 43.66, 63.00 and $47.66 \mathrm{cfu} \times 10^{5} \mathrm{~g}^{-1}$ oven dry soil) were recorded under treatment $\mathrm{T}_{5}\{(75 \% \mathrm{~N}(\mathrm{FYM})$ basal + $25 \%$ N (V/C) at 25 DAT + Azospirillum@ $5 \mathrm{~kg} \mathrm{ha}^{-1}+$ PSB @ $5 \mathrm{~kg} \mathrm{ha}^{-1}+\mathrm{KSB} @ 5$ $\left.\left.\mathrm{kg} \mathrm{ha}^{-1}\right)\right\}$ at panicle initiation stage trend was similar at harvesting stage. The treatment $\mathrm{T}_{5}$ significantly increased dehydrogenase activity by $81.62 \%, 10.80 \%, 24.86 \%, 15.66 \%$, $17.83 \%$ and $18.91 \%$ when compared with application of $\mathrm{T}_{1}$ (RDF), $\mathrm{T}_{3}\{(100 \% \mathrm{~N} \mathrm{FYM})$ as basal $)\}, T_{7}\left\{(100 \% \mathrm{~N}(\mathrm{GM})\}, \mathrm{T}_{8}\{(50 \% \mathrm{~N}(\mathrm{GM})+50 \% \mathrm{~N}(\mathrm{~V} / \mathrm{C})\right.$ at $25 \mathrm{DAT})\}, \mathrm{T}_{9}\{(75 \% \mathrm{~N}$ $(\mathrm{GM})+25 \% \mathrm{~N}(\mathrm{~V} / \mathrm{C})$ at 25 DAT + Azospirillum@ $5 \mathrm{~kg} \mathrm{ha}^{-1}+\mathrm{PSB} @ 5 \mathrm{~kg} \mathrm{ha}^{-1}+\mathrm{KSB} @ 5$ $\left.\left.\mathrm{kg} \mathrm{ha}^{-1}\right)\right\}$ and $\mathrm{T}_{10}\{(75 \% \mathrm{~N}(\mathrm{GM})+25 \% \mathrm{~N}(\mathrm{~V} / \mathrm{C})$ at 25 DAT + Panchagabhya on foliar application )\}, respectively. The maximum grain yield of paddy $\left(27.39 \mathrm{q} \mathrm{ha}^{-1}\right)$ was also recorded under treatment $T_{5}$ which was found to be most effective in modifying soil microbial population, microbial community structure and grain yield of scented rice.
\end{abstract}

Keywords: Microbial inoculants, Organic fertilizer, Oryza sativa L., Yield

\section{Article Info}

DOI: 10.31018/jans.v10i3.1831

Received: July 25, 2018

Revised: August 14, 2018

Accepted: August 17, 2018

\section{How to Cite}

Sah, A.K. et al. (2018). Effect of organic fertilizer and microbial inoculants on soil biological properties and yield of scented rice (Oryza sativa L.). Journal of Applied and Natural Science, 10(3): 995 - 1002

\section{INTRODUCTION}

Indiscriminate use of chemical fertilizers and pesticides during green revolution period resulted in several harmful effects on soil, water and air causing their pollution. This has reduced the productivity of the soil by deteriorating soil health in terms of soil fertility and biological activity. The excess use of pesticides has led to the entry of harmful com- pounds into food chain, death of natural enemies and development of resistance against pesticides. Hence, enhancement and maintenance of system productivity and resource quality is essential for sustainable agriculture. The high cost of these products, the difficulties of meeting demand for them, and their harmful environmental legacy have encouraged scientists to develop alternative strategies to raise productivity, with microbes play- 
ing a central role in these efforts (Vaxevanidou et al., 2015). It is believed that application of organic fertilizer and biofertilizers can solve many of these problems as this system is believed to maintain soil productivity and pest control by enhancing natural processes and cycles in harmony with environment.

Farm yard manure supplies nitrogen, phosphorus, potassium and micronutrients like $\mathrm{Fe}, \mathrm{S}$, Mo and $\mathrm{Zn}$ etc. It improves physical and chemical properties and health of soil such as aggregation, aeration, permeability, water holding capacity, slow release of nutrients, increase in cation exchange capacity, stimulation of soil flora and fauna etc. On an average, it contains $0.50,0.17$ and 0.55 per cent of N, P and K, respectively (Gaur, 1991). Vermicompost is an aerobically degraded organic matter produced with the help of worms. It contains 0.80 to $1.10 \% \mathrm{~N}, 0.40$ to $0.80 \% \mathrm{P} 2 \mathrm{O} 5$ and 0.80 to $0.98 \% \mathrm{~K} 2 \mathrm{O}, 10$ to $52 \mathrm{ppm} \mathrm{Cu}, 186.60 \mathrm{ppm}$ $\mathrm{Zn}, 930.00 \mathrm{ppm}$ Fe and plant growth promoting substances such as NAA, cytokinins, gibberellins, etc. (Giraddi, 2001). It improves physico-chemical properties of the soil and enhances the microbial, crop growth and yield (Vasanthiand Kumaraswamy, 1999). Use of panchagavya and fish amino acid improves the soil and plants health also providing protective measures against plant diseases. Panchagavya and fish amino acid enhances the biological efficiency of the crop plants and disease resistance (Sarkar et al., 2014).

Biofertilizers play a significant role in fixing atmospheric nitrogen, production of growth promoting substances and making phosphorous available to the plants hence the application of biofertilizers is very essential to the plant (Upadhayay et al., 1999). Generally, plant growth promoting rhizobacteria facilitate the plant growth directly by either assisting in resource acquisition (Ahemad and Kibret, 2014). Considering with these facts the present investigation has been formulated to evaluate the effect of organic inputs (viz., Vermicompost, FYM, neem cake, green manures and Panchgavya) and microbial inoculants (viz., Azospirillum, Phosphorus Solubilizing Bacteria (PSB) and Potassium Solubilizing Bacteria (KSB)) on soil properties under rice rhizosphere.Soil enzymes, usually produced by the soil inhabitants are known to play an important role in maintaining soil health and sustainability. The enzymatic activity in the soil is mainly of microbial origin and is derived from intracellular, cell-associated or free enzymes (Das and Verma 2011). Soil enzymes determine the various metabolic processes of soil. Different soils have different enzyme levels due to the fact that each soil type has different amounts of organic matter content, nutrients and activity of its living organisms. Soil enzyme activities are very sensitive to both natural and anthropogenic disturbances and show a quick response to the induced changes (Dick 1997).

Rice (Oryza sativa L.) is a predominant staple food and a major source of dietary carbohydrate for more than half of the world's population. Freshly harvested rice grains contain about $80 \%$ carbohydrate which includes starch, glucose, sucrose and dextrin (Verma and Srivastav, 2017).Rice is the second most widely grown cereal crop and is the staple food for more than half of the world's population. As reported by DACFW(2016), Rice is grown over an area of 43.39 Mha in India with an annual productivity of $2.4 \mathrm{t} \mathrm{ha}^{-1}$. Bihar is the $6^{\text {th }}$ largest producer of Rice in India after West Bengal, Uttar Pradesh, Punjab, Tamil Nadu and Andhra Pradesh. Land resources are degrading due to intensive cultivation and use of chemical fertilizers, pesticide and weedicide. This has caused environmental imbalance and it is causing problem to all living being on the Earth. The soil is becoming low and deficient in organic content. Persistent nutrient depletion is posing a greater threat to the sustainable agriculture. Therefore, there is an urgent need to reduce the usage of chemical fertilizers and in turn increase the usage of organic manures and organic fertilizers. Rice production currently depends on the large scale use of chemical fertilizers which pose an environmental hazard for rice producing areas. Organic manure has the capacity to fulfil nutrient demand of crops adequately and promotes the activity of macro and micro flora in the soil. The area under scented rice varieties is increasing day by day with the opening of the world market as well as increased domestic consumption due to their premium quality. Under this situation organic cultivation of scented rice is a good option for earning more money by the marginal rice growers of Bihar by narrowing the cost of cultivation simultaneously with production of high value scented organic rice. In cultivation of scented rice under organic farming system, weeds are one of the hindrances for getting profitable yield. Under this system the chemicals are banned for controlling weeds.

There are several reports which show that the combined and/or sole application of organic manures and biofertilizers increases yield and influences the quality attributes in crops (Bahadur et al., 2006) such as rice crop. Keeping this in view, the present investigation was undertaken to find out the suitable combination of organic manures and biofertilizers which can boost biological property of soil and better yield of scented rice i.e. Katarni in this case, which has been reported to have a low recommended dose of fertilizers and the nutrient requirement can be met through sole application of organic material.

\section{MATERIALS AND METHODS}

The present study was undertaken to evaluate the response of organic fertilizers and biofertilizer on 
soil biological properties and yield of scented rice under field condition during the Kharif season of 2017 with a promising var. Bhagalpur Katarni, at the research farm of Bihar Agricultural University, Sabour, Bhagalpur, India. The organic fertilizer were locally procured from the Bihar Agricultrural University, Dairy farm and microbial inoculants viz., Phosphorus Solubilizing Bacteria (PSB) (Burkholderiacepecia), Potassium Solubilizing Bacteria (KSB) (Fraturiaaurentia) and Azospirillum (Azospirillumvirilandii) were obtained from the Biofertilizer Production Unit, Bihar Agricultural University, Sabour.

The experimental soil was well drained Aquic Hapludoll silty clay loam having $\mathrm{pH} 7.3$, Electrical conductivity $0.68, \mathrm{dSm}^{-1}$ organic carbon 0.51 per cent, available phosphorus $12.50 \mathrm{~kg} \mathrm{ha}^{-1}$, available potassium $190.00 \mathrm{~kg} \mathrm{ha}^{-1}$ and nitrogen 175.00 $\mathrm{kg} \mathrm{ha}^{-1}$. The experiment included ten treatments which comprised of $\mathrm{T}_{1}-100 \% \mathrm{RDF}, \mathrm{T}_{2^{-}} 1 / 3 \mathrm{~N}$ $(\mathrm{FYM})+1 / 3 \mathrm{~N}(\mathrm{~V} / \mathrm{C})+1 / 3 \mathrm{~N}$ ( Neem cake ), $\mathrm{T}_{3}$ $100 \% \mathrm{~N}$ (FYM) as basal application, $\mathrm{T}_{4}-50 \% \mathrm{~N}$ (FYM) as basal application + 50\% N (V/C), $\mathrm{T}_{6^{-}}$ $75 \% \mathrm{~N}(\mathrm{FYM})$ as basal application $+25 \% \mathrm{~N}(\mathrm{~V} / \mathrm{C})$ Azospirillum + PSB + KSB, $\mathrm{T}_{7}-75 \% \mathrm{~N}$ (FYM) as basal application $+25 \% \mathrm{~N}(\mathrm{~V} / \mathrm{C})+$ Panchgabhya as foliar application at 25 DAT, $\mathrm{T}_{8}-100 \% \mathrm{~N}$ (Green manure), $\mathrm{T}_{9}-50 \% \mathrm{~N}$ (Green manure) $50 \% \mathrm{~N}(\mathrm{~V} /$ C), $\mathrm{T}_{10}-75 \% \mathrm{~N}$ (Green Manure) $+25 \% \mathrm{~N}(\mathrm{~V} / \mathrm{C})+$ Azospirillum + PSB + KSB and 75\% N (Green Manure) $+25 \% \mathrm{~N}(\mathrm{~V} / \mathrm{C})+$ Panchgabhya asfoliar application at 25 DAT.The irrigation has applied as per requirement of the crop.Rhizosphere samples were obtained by collecting the soil adhering to the roots. The $10 \mathrm{~g}$ of soil samples were placed in an Erlenmeyer flask containing $90 \mathrm{ml}$ of sterilized distilled water, and shaken for $30 \mathrm{~min}$. Tenfold series dilutions were prepared, and appropriate dilutions were plated in specific media and for the isolation of bacteria, fungi and actinomycetes, the Plate Count Agar, Czapek-Dox Agar and Kenknight and Munaier's Medium, respectively were used. The numbers of colony forming cells were determined in each plot by serial dilution pour plate method (Subbha, 1986).

Dehydrogenase activity was determined by using procedure as outlined by Casidaet al., $1964.1 \mathrm{~g}$ air-dried soil, was taken in an air-tight screwcapped test tube (15 ml capacity). $0.2 \mathrm{ml}$ of $3 \%$ TTC solution in each of the tubes were added to saturate soil. $0.5 \mathrm{ml}$ of $1 \%$ glucose solution was added in each tube. Tapping was done gently to drive out tapped oxygen and thus water seal was formed above the soil. Incubation was done at $28^{\circ}$ $\mathrm{C}$ for $24 \mathrm{~h}$. After incubation, $10 \mathrm{ml}$ methanol was added and shaken vigorously, allowed to stand for $6 \mathrm{~h}$. clear pink coloured supernatant was withdrawn and reading was taken with a spectrophotometer at a wavelength at $485 \mathrm{~nm}$. However, acid and alkaline phosphatase activity was determined by following procedure as outlined by Tabatabai and Bremer, 1969. For each soil, two sets of $1 \mathrm{~g}$ (oven dry equivalent) soil $(<2 \mathrm{~mm})$ were taken in $50 \mathrm{ml}$ conical flasks. Out of these, one set were used as control. Then $0.2 \mathrm{ml}$ toluene and $4 \mathrm{ml}$ of MUB (Modified universal buffer) ( $\mathrm{pH} 6.5$ or 11) was added and $1 \mathrm{ml}$ of $\mathrm{p}$-nitrophenyl phosphate solution was added to one set of samples. After swirling both flasks for few seconds for mixing the contents, it was stopped and placed in an incubator at $37^{\circ} \mathrm{C}$ for one hour. After incubation, the stoppers were removed and $1 \mathrm{ml}$ of $0.5 \mathrm{M} \mathrm{CaCl}_{2}$ and $4 \mathrm{ml}$ of $0.5 \mathrm{M} \mathrm{NaOH}$ was added. Flasks were swirled for few seconds and $1 \mathrm{ml}$ of p-nitrophenyl phosphate solution was added to remaining set of samples. All the suspension was filtered through Whatman No. 1 filter paper quickly and yellow colour intensity were measured at $440 \mathrm{~nm}$ wavelength. After comparing with standard curve, finally acid and alkaline phosphatase activity was expressed as $\mu \mathrm{g}$ $\mathrm{p}$-nitrophenol (PNP) released $\mathrm{g}^{-1}$ soil $\mathrm{h}^{-1}$. The obtained field experiment data were analyzed by using standard procedure for Randomized Block Design (RBD) with the help of a computer applying analysis of variance (ANOVA) technique (Snedecor and Cochron, 1971). The differences among treatments were compared by applying "F" test of significance at 5 per cent of probability and $P$ values was used to examine differences among treatment means.

\section{RESULTS AND DISCUSSION}

Effect on soil microbial population: The obtained results (Table 1 ) showed that the maximum microbial population (Bacteria, Actinomycetes and fungi) was observed at panicle initiation stage of rice in comparison to harvesting stage under applied all treatments. It might be due to the addition of FYM or vermicompost in soil which leads to an increase in microbial population and activity due to more amounts of available carbon and nutrients like $\mathrm{N}$ and $\mathrm{P}$ to soil micro organism which provide more energy. Later on, the nutrients were exhausted due to crop uptake which reduces the microbial population in soil. It may also be due to secretion of various root exudates by rice roots, utilized by the bacteria for their carbon requirement and leads to increase in multiplication of the microbial population. The application of all organic amendments and microbial inoculants significantly increased bacterial population in soil at both panicle and harvesting stages over recommended dose of $N, P$ and $\mathrm{K}$. The addition of organic inputs enhanced the microbial counts in soil, which might be due to carbon addition and changes in physico-chemical properties of soil.

The maximum bacterial population $(71.66 \mathrm{cfu} \times$ $10^{5} \mathrm{~g}^{-1}$ soil and $40.00 \mathrm{cfu} \times 10^{5} \mathrm{~g}^{-1}$ soil), fungi population $\left(27.33 \mathrm{cfu} \times 10^{4} \mathrm{~g}^{-1}\right.$ soil and $22.66 \mathrm{cfu} \times 10^{4}$ $\mathrm{g}^{-1}$ soil) and actinomycetes population (57.66 cfu $\times$ 
Sah, A.K. et al. / J. Appl. \& Nat. Sci. 10 (3): 995 - 1002 (2018)

Table 1. Response of organic inputs and microbial inoculants on microbial population status of experimental soil under rice rhizosphere.

\begin{tabular}{|c|c|c|c|c|c|c|}
\hline \multirow[t]{2}{*}{ Treatments } & \multicolumn{2}{|c|}{$\begin{array}{l}\text { Bacteria } \\
\left(\text { cfu } \times 10^{5} \mathrm{~g}^{-1} \text { soil) }\right.\end{array}$} & \multicolumn{2}{|c|}{$\begin{array}{l}\text { Fungi } \\
\left(\mathrm{cfu} \times 10^{4} \mathrm{~g}^{-1} \text { soil) }\right.\end{array}$} & \multicolumn{2}{|c|}{$\begin{array}{l}\text { Actinomycetes } \\
\text { (cfu } \times 10^{5} \mathrm{~g}^{-1} \text { soil) }\end{array}$} \\
\hline & Panicle & Harvest & Panicle & Harvest & Panicle & Harvest \\
\hline $\mathrm{T}_{1}:$ control ( R:D:F) & 20.00 & 13.66 & 12.00 & 8.33 & 20.66 & 13.33 \\
\hline $\mathrm{T}_{2}: 1 / 3 \mathrm{~N}(\mathrm{FYM})+1 / 3 \mathrm{~N}(\mathrm{VC})+1 / 3 \mathrm{~N}(\mathrm{NC})$ & 64.33 & 29.33 & 20.33 & 18.00 & 49.33 & 35.00 \\
\hline $\begin{array}{l}\mathrm{T}_{3}: 100 \% \mathrm{~N}(\mathrm{FYM}) \text { as basal } \\
\mathrm{T}_{4}: 50 \% \mathrm{~N}(\mathrm{FYM}) \text { as basal }+50 \% \mathrm{~N}(\mathrm{VC}) \text { at } 25\end{array}$ & 56.33 & 26.33 & 19.00 & 12.66 & 43.00 & 33.00 \\
\hline $\begin{array}{l}\text { DAT } \\
\mathrm{T}_{5}: 75 \% \mathrm{~N}(\mathrm{FYM}) \text { basal }+25 \% \mathrm{~N}(\mathrm{VC}) \text { at } 25 \text { DAT }\end{array}$ & 67.00 & 34.00 & 23.00 & 20.33 & 52.00 & 40.33 \\
\hline $\begin{array}{l}+ \text { Azospirillum }+\mathrm{PSB}+\mathrm{KSB} \\
\end{array}$ & 71.66 & 40.00 & 27.33 & 22.66 & 57.66 & 46.33 \\
\hline DAT + Panchagavya on foliar application & 71.00 & 39.33 & 27.33 & 22.00 & 57.00 & 46.00 \\
\hline $\mathrm{T}_{7}: 100 \% \mathrm{~N}(\mathrm{GM})$ & 36.33 & 20.00 & 15.00 & 10.00 & 31.33 & 28.00 \\
\hline $\begin{array}{l}\mathrm{T}_{8}: 50 \% \mathrm{~N}(\mathrm{GM})+50 \% \mathrm{~N}(\mathrm{VC}) \text { at } 25 \text { DAT } \\
\mathrm{T}_{9}: 75 \% \mathrm{~N}(\mathrm{GM})+25 \% \mathrm{~N}(\mathrm{VC}) \text { at } 25 \text { DAT }+\end{array}$ & 58.33 & 24.33 & 17.33 & 16.00 & 40.66 & 31.33 \\
\hline Azospirillum + PSB + KSB & 53.00 & 22.66 & 16.33 & 14.33 & 35.33 & 30.33 \\
\hline $\begin{array}{l}\mathrm{T}_{10}: 75 \% \mathrm{~N}(\mathrm{GM})+25 \% \mathrm{~N}(\mathrm{VC}) \text { at } 25 \mathrm{DAT}+\text { Pan- } \\
\text { chagavya on foliar application }\end{array}$ & 53.66 & 22.66 & 16.00 & 14.00 & 35.33 & 30.00 \\
\hline $\mathrm{CD}(0.05)$ & 5.29 & 7.73 & 3.60 & 6.62 & 5.99 & 7.75 \\
\hline $\mathrm{SE}(\mathrm{m})$ & 1.76 & 2.58 & 1.20 & 2.21 & 2.00 & 2.58 \\
\hline CV (\%) & 5.55 & 16.43 & 10.75 & 24.19 & 8.20 & 13.44 \\
\hline
\end{tabular}

*VC-Vermicompost, NC-Neemcake, GM-Green manure, PSB - Phosphate Solubilzing bacteria, KSB - Potassium Solubilzing bacteria, FYM-Farm yard

Table 2. Effect of organic inputs and microbial inoculants on Azospirillum, PSB and KSB population.

\begin{tabular}{|c|c|c|c|c|c|c|}
\hline \multirow[t]{2}{*}{ Treatments } & \multicolumn{2}{|c|}{$\begin{array}{l}\text { Azospirillum } \\
\text { (cfu } \times 10^{5} \mathrm{~g}^{-1} \text { soil) }\end{array}$} & \multicolumn{2}{|c|}{$\begin{array}{l}\text { PSB } \\
\text { (cfux } 10^{5} \mathrm{~g}^{-1} \text { soil) }\end{array}$} & \multicolumn{2}{|c|}{$\begin{array}{l}\text { KSB } \\
\text { (cfu } \times 10^{5} \mathrm{~g}^{-1} \text { soil) }\end{array}$} \\
\hline & Panicle & Harvest & Panicle & Harvest & Panicle & Harvest \\
\hline $\mathrm{T}_{1}:$ control ( R:D:F) & 13.00 & 8.66 & 18.33 & 15.00 & 10.33 & 6.33 \\
\hline $\mathrm{T}_{2}: 1 / 3 \mathrm{~N}(\mathrm{FYM})+1 / 3 \mathrm{~N}(\mathrm{VC})+1 / 3 \mathrm{~N}(\mathrm{NC})$ & 34.00 & 28.33 & 49.33 & 31.66 & 39.00 & 30.00 \\
\hline $\begin{array}{l}\mathrm{T}_{3}: 100 \% \mathrm{~N}(\mathrm{FYM}) \text { as basal } \\
\mathrm{T}_{4}: 50 \% \mathrm{~N}(\mathrm{FYM}) \text { as basal }+50 \% \mathrm{~N}(\mathrm{VC}) \text { at } 25\end{array}$ & 26.00 & 25.66 & 37.00 & 26.33 & 34.66 & 27.33 \\
\hline $\begin{array}{l}\text { DAT } \\
T_{5}: 75 \% \mathrm{~N}(\mathrm{FYM}) \text { basal }+25 \% \mathrm{~N}(\mathrm{VC}) \text { at } 25 \text { DAT }\end{array}$ & 36.33 & 31.66 & 53.33 & 35.66 & 42.00 & 32.00 \\
\hline $\begin{array}{l}+ \text { Azospirillum + PSB + KSB } \\
\mathrm{T}_{6}: 75 \%(\mathrm{FYM}) \text { as basal }+25 \% \mathrm{~N}(\mathrm{VC}) \text { at } 25\end{array}$ & 43.66 & 35.66 & 63.00 & 41.66 & 47.66 & 37.00 \\
\hline DAT + Panchagavya on foliar application & 43.33 & 35.33 & 63.00 & 41.00 & 47.00 & 36.33 \\
\hline $\mathrm{T}_{7}: 100 \% \mathrm{~N}(\mathrm{GM})$ & 22.66 & 16.33 & 27.33 & 19.33 & 27.00 & 17.66 \\
\hline $\begin{array}{l}\mathrm{T}_{8}: 50 \% \mathrm{~N}(\mathrm{GM})+50 \% \mathrm{~N}(\mathrm{VC}) \text { at } 25 \mathrm{DAT} \\
\mathrm{T}_{9}: 75 \% \mathrm{~N}(\mathrm{GM})+25 \% \mathrm{~N}(\mathrm{VC}) \text { at } 25 \text { DAT }+\end{array}$ & 32.66 & 21.00 & 35.00 & 24.00 & 33.66 & 25.66 \\
\hline $\begin{array}{l}\text { Azospirillum + PSB + KSB } \\
\mathrm{T}_{10}: 75 \% \mathrm{~N}(\mathrm{GM})+25 \% \mathrm{~N}(\mathrm{VC}) \text { at } 25 \mathrm{DAT}+\end{array}$ & 30.00 & 20.66 & 32.33 & 22.33 & 30.00 & 22.66 \\
\hline Panchagavya on foliar application & 30.00 & 20.00 & 33.00 & 22.00 & 29.33 & 23.66 \\
\hline$C D(0.05)$ & 6.09 & 5.54 & 9.65 & 6.57 & 6.38 & 3.88 \\
\hline $\mathrm{SE}(\mathrm{m})$ & 2.03 & 1.85 & 3.22 & 2.19 & 2.13 & 1.29 \\
\hline CV $(\%)$ & 11.32 & 13.18 & 13.56 & 13.63 & 10.83 & 8.68 \\
\hline
\end{tabular}

*VC-Vermicompost, NC-Neemcake, GM-Green manure, PSB - Phosphate Solubilzing bacteria, KSB - Potassium Solubilzing bacteria, FYM-Farm yard

$10^{5} \mathrm{~g}^{-1}$ soil and $46.33 \mathrm{cfu} \times 10^{5} \mathrm{~g}^{-1}$ soil) are flourished in the treatment $\mathrm{T}_{5}\{(75 \% \mathrm{~N}$ (FYM) basal + $25 \% \mathrm{~N}(\mathrm{~V} / \mathrm{C})$ at $25 \mathrm{DAT}+$ Azospirillum@ $5 \mathrm{~kg} \mathrm{ha}-$ $1+$ PSB @ $\left.\left.5 \mathrm{~kg} \mathrm{ha}^{-1}+\mathrm{KSB} @ 5 \mathrm{~kg} \mathrm{ha}^{-1}\right)\right\}$ at both the panicle and harvesting stage. The recommended dose of fertilizer (RDF) resulted in lower values of microbial populations than organic manure treatments. Microbial population composition and density is an important attribute of soil organic matter quality, as it provides an indication of a soil's ability to store and recycle nutrients and energy. It also serves as a sensitive indicator of change and future trends in organic matter level.
The results were in the conformity of the results of Meena et al., (2015) who conducted a field experiment and found that application of $120 \mathrm{~kg} \mathrm{~N} \mathrm{ha}^{-1}$ either through FYM (Farm Yard Manure equivalent to $120 \mathrm{~kg} \mathrm{~N}$ ha $^{-1}$ ) or vermicompost (Vermicompost equivalent to $120 \mathrm{~kg} \mathrm{~N} \mathrm{ha}^{-1}$ ) resulted in maximum microbial population of bacteria (28.60 and 27.12 cfu1 $10^{5} \mathrm{~g}^{-1}$ soil), fungi (23.96 and $22.17 \mathrm{cfu} 10^{4} \mathrm{~g}^{-1}$ soil) and actinomycetes (14.16 and 12.92 cfu102 $\mathrm{g}^{-1}$ soil), respectively. It is an established fact that compost has considerable amount carbon and nutrients, which support of growth and activity of microorganism in soil. Simi- 
Table 3. Effect of organic inputs and biofertilizers on soil enzymatic activities.

\begin{tabular}{|c|c|c|c|c|c|c|}
\hline \multirow[t]{2}{*}{ Treatments } & \multicolumn{2}{|c|}{$\begin{array}{l}\text { Dehydrgenase } \\
\left(\mu \mathrm{g} \text { TPF g- }{ }^{-1} \text { soil } 24\right. \\
\left.\mathrm{hr}^{-1}\right)\end{array}$} & \multicolumn{2}{|c|}{$\begin{array}{l}\text { Alkaline phospha- } \\
\text { tase }\left(\mathrm{mg}^{-} \text {PNP } \mathrm{g}^{-1}\right. \\
\left.\text { soil } \mathrm{hr}^{-1}\right)\end{array}$} & \multicolumn{2}{|c|}{$\begin{array}{l}\text { Acid phospha- } \\
\text { tase }\left(\mathrm{mg}^{-1} \text { PNP } \mathrm{g}^{-1}\right. \\
\left.\text { soil } \mathrm{hr}^{-1}\right)\end{array}$} \\
\hline & Panicle & Harvest & Panicle & Harvest & Panicle & Harvest \\
\hline $\mathrm{T}_{1}:$ control ( R:D:F) & 11.33 & 7.66 & 15.00 & 8.00 & 13.00 & 9.33 \\
\hline $\mathrm{T}_{2}: 1 / 3 \mathrm{~N}(\mathrm{FYM})+1 / 3 \mathrm{~N}(\mathrm{VC})+1 / 3 \mathrm{~N}(\mathrm{NC})$ & 56.33 & 39.00 & 58.66 & 37.00 & 57.00 & 35.33 \\
\hline $\begin{array}{l}\mathrm{T}_{3}: 100 \% \mathrm{~N}(\mathrm{FYM}) \text { as basal } \\
\mathrm{T}_{4}: 50 \% \mathrm{~N}(\mathrm{FYM}) \text { as basal }+50 \% \mathrm{~N}(\mathrm{VC}) \text { at } 25\end{array}$ & 55.00 & 37.00 & 54.66 & 32.77 & 54.33 & 31.00 \\
\hline $\begin{array}{l}\text { DAT } \\
T_{5}: 75 \% \mathrm{~N}(\mathrm{FYM}) \text { basal }+25 \% \mathrm{~N}(\mathrm{VC}) \text { at } 25 \text { DAT }\end{array}$ & 58.00 & 42.66 & 61.00 & 39.33 & 60.33 & 40.00 \\
\hline $\begin{array}{l}+ \text { Azospirillum }+\mathrm{PSB}+\mathrm{KSB} \\
\mathrm{T}_{6}: 75 \% \text { (FYM) as basal }+25 \% \mathrm{~N}(\mathrm{VC}) \text { at } 25\end{array}$ & 61.66 & 48.00 & 63.33 & 43.8 & 68.66 & 47.66 \\
\hline DAT + Panchagavya on foliar application & 61.00 & 47.33 & 63.00 & 42.4 & 68.33 & 47.33 \\
\hline $\mathrm{T}_{7}: 100 \% \mathrm{~N}(\mathrm{GM})$ & 46.33 & 28.00 & 47.66 & 30.88 & 50.00 & 24.33 \\
\hline $\mathrm{T}_{8}: 50 \% \mathrm{~N}(\mathrm{GM})+50 \% \mathrm{~N}(\mathrm{VC})$ at $25 \mathrm{DAT}$ & 52.00 & 34.00 & 52.66 & 29.11 & 53.00 & 29.33 \\
\hline $\begin{array}{l}\mathrm{T}_{9}: 75 \% \mathrm{~N}(\mathrm{GM})+25 \% \mathrm{~N}(\mathrm{VC}) \text { at } 25 \mathrm{DAT}+ \\
\text { Azospirillum }+\mathrm{PSB}+\mathrm{KSB} \\
\mathrm{T}_{10}: 75 \% \mathrm{~N}(\mathrm{GM})+25 \% \mathrm{~N}(\mathrm{VC}) \text { at } 25 \mathrm{DAT}+\end{array}$ & 50.66 & 31.66 & 51.00 & 22.66 & 51.33 & 26.33 \\
\hline Panchagavya on foliar application & 50.00 & 31.33 & 50.33 & 21.55 & 51.00 & 26.00 \\
\hline$C D(0.05)$ & 5.96 & 2.57 & 3.86 & 9.15 & 3.48 & 2.89 \\
\hline $\mathrm{SE}(\mathrm{m})$ & 1.99 & 0.86 & 1.29 & 3.05 & 1.16 & 0.96 \\
\hline CV $(\%)$ & 6.87 & 4.30 & 4.32 & 16.79 & 3.83 & 5.29 \\
\hline
\end{tabular}

*VC-Vermicompost, NC-Neemcake, GM-Green manure, PSB - Phosphate Solubilzing bacteria, KSB - Potassium Solubilzing bacteria, FYM-Farm yard

Table 4. Effect of application of organic fertilizers yield and yield parameters of rice.

\begin{tabular}{|c|c|c|c|}
\hline Treatments & $\begin{array}{l}\text { Biological } \\
\text { yield (q ha }{ }^{-1} \text { ) }\end{array}$ & $\begin{array}{l}\text { Grain yield } \\
\left(\mathrm{q} \mathrm{ha} \mathrm{h}^{-1}\right)\end{array}$ & $\begin{array}{l}\text { Straw yield } \\
\left(\text { qha }^{-1}\right)\end{array}$ \\
\hline $\mathrm{T}_{1}:$ control ( R:D:F) & 65.16 & 29.09 & 36.06 \\
\hline$T_{2}: 1 / 3 N(F Y M)+1 / 3 N(V C)+1 / 3 N(N C)$ & 60.87 & 25.36 & 35.50 \\
\hline $\mathrm{T}_{3}: 100 \% \mathrm{~N}(\mathrm{FYM})$ as basal & 57.09 & 24.74 & 32.35 \\
\hline $\begin{array}{l}\mathrm{T}_{4}: 50 \% \mathrm{~N}(\mathrm{FYM}) \text { as basal }+50 \% \mathrm{~N}(\mathrm{VC}) \text { at } 25 \mathrm{DAT} \\
\mathrm{T} 5.75 \% \mathrm{~N}(\mathrm{FYM}) \text { basal }+25 \% \mathrm{~N}(\mathrm{VC}) \text { at } 25 \mathrm{DAT}+\text { Azospiril- }\end{array}$ & 65.20 & 26.86 & 38.33 \\
\hline $\begin{array}{l}\text { lum }+ \text { PSB + KSB } \\
\text { T. } 75 \% \text { (FYM) as basal }+25 \% \text { N (VC) at } 25 \text { DAT + Pan- }\end{array}$ & 65.27 & 27.39 & 37.88 \\
\hline chagavya on foliar application & 64.85 & 27.10 & 37.7 \\
\hline $\mathrm{T}_{7}: 100 \% \mathrm{~N}(\mathrm{GM})$ & 52.93 & 22.58 & 30.35 \\
\hline $\begin{array}{l}\mathrm{T}_{8}: 50 \% \mathrm{~N}(\mathrm{GM})+50 \% \mathrm{~N}(\mathrm{VC}) \text { at } 25 \mathrm{DAT} \\
\mathrm{T}_{9}: 75 \% \mathrm{~N}(\mathrm{GM})+25 \% \mathrm{~N}(\mathrm{VC}) \text { at } 25 \text { DAT }+ \text { Azospirillum }+\end{array}$ & 50.59 & 23.87 & 26.72 \\
\hline $\begin{array}{l}\mathrm{PSB}+\mathrm{KSB} \\
\\
\end{array}$ & 54.66 & 23.09 & 31.57 \\
\hline foliar application & 53.88 & 23.03 & 30.85 \\
\hline CD $(0.05)$ & 6.58 & 3.91 & N/A \\
\hline $\mathrm{SE}(\mathrm{m})$ & 2.19 & 1.30 & 2.79 \\
\hline CV (\%) & 6.45 & 8.94 & 14.32 \\
\hline
\end{tabular}

*VC-Vermicompost, NC-Neemcake, GM-Green manure, PSB - Phosphate Solubilzing bacteria, KSB - Potassium Solubilzing bacteria, FYM-Farm yard manure

lar results were found by the Krishnakumar et al. (2005) they studied the microbial populations influenced by organic farming and found that application of FYM + NC (Neem Cake) showed significantly higher bacterial population $\left(38.6 \mathrm{cfu} \mathrm{g}^{-1}\right.$ of soil), fungal population (15.2 $\mathrm{cfu} \mathrm{g}^{-1}$ of soil) and Actinomycetes population (12.2 $\mathrm{cfu} \mathrm{g}^{-1}$ of soil) than absolute control (15.9 $\mathrm{cfu} \mathrm{g}^{-1}$ of soil).

Azospirillum: Presented experimental findings (Table 2) showed that the application of organic source of nutrient and biofertilizers (Azospirillum, KSB and PSB), significantly increase Azospirillum count in soil over recommended dose of fertilizer (RDF). It might be due to addition of organic in- puts which leads to changes in organic carbon content and physico-chemical properties of soil. The increasing the microbial population with the application of manure might be due to assimilated growth and microbial activity of soil (Upadhyayet al 2011). Similar results were obtained by Meena et al., 2015 who reported that the application of leaf compost equivalent to $120 \mathrm{~kg} \mathrm{~N}$ ha $^{-1}$ resulted in higher amount of microbial population then RDF. At panicle initiation stage Azospirillum count in soil were recorded higher than after harvest, it might be due to the availability of congenial environment and source of carbon for the bacterial growth and their multiplication. The plant roots 
secreted various types of organic acids, which is an easily available source of food for soil microorganism (Dotaniyaet al., 2013). The application of $\mathrm{T}_{5}(75 \% \mathrm{~N}$ (FYM) basal $+25 \% \mathrm{~N}(\mathrm{~V} / \mathrm{C})$ at 25 DAT + Azospirillum@ 5 kg ha-1 + PSB @ 5 kg ha ${ }^{1}+$ KSB @ 5 kg ha ${ }^{-1}$ ) significantly increased Azospirillum count in soil over $\mathrm{T}_{1}(\mathrm{R}: \mathrm{D}: \mathrm{F}-40 \mathrm{~kg}$ $\mathrm{N}+30 \mathrm{~kg} \mathrm{P}+20 \mathrm{~kg} \mathrm{~K}), \mathrm{T}_{2}(1 / 3 \mathrm{~N}(\mathrm{FYM})+1 / 3 \mathrm{~N}$ (VC) $+1 / 3 \mathrm{~N}(\mathrm{NC}), \mathrm{T}_{3}(100 \% \mathrm{~N} \mathrm{FYM})$ as basal)\}, $\mathrm{T}_{4}(50 \% \mathrm{~N}(\mathrm{FYM})$ as basal $+50 \% \mathrm{~N}(\mathrm{~V} / \mathrm{C})$ at 25 DAT), $\mathrm{T}_{7}\left(100 \% \mathrm{~N}(\mathrm{GM}), \mathrm{T}_{8}(50 \% \mathrm{~N}(\mathrm{GM})+50\right.$ $\% \mathrm{~N}(\mathrm{~V} / \mathrm{C})$ at $25 \mathrm{DAT}), \mathrm{T}_{9}(75 \% \mathrm{~N}(\mathrm{GM})+25 \% \mathrm{~N}$ (V/C) at 25 DAT + Azospirillum@ $5 \mathrm{~kg} \mathrm{ha}^{-1}+\mathrm{PSB}$ @ $\left.5 \mathrm{~kg} \mathrm{ha}^{-1}+\mathrm{KSB} @ 5 \mathrm{~kg} \mathrm{ha}^{-1}\right)$ and $\mathrm{T}_{10}(75 \% \mathrm{~N}$ $(\mathrm{GM})+25 \% \mathrm{~N}(\mathrm{~V} / \mathrm{C})$ at 25 DAT + Panchagavya on foliar application ant at par w3ith the application of $\mathrm{T}_{6}(75 \% \mathrm{~N}(\mathrm{FYM})$ as basal $+25 \% \mathrm{~N}(\mathrm{~V} / \mathrm{C})$ at 25 DAT + Panchagavya on foliar application) it may be due to the availability of nutrients from the FYM and vermicompost for longer period of time to the bacteria. The results are similar to the findings of Brar et al., 2017 who found significantly higher bacterial population $\left(28.10 \times 10^{8} \mathrm{cfu} \mathrm{g}^{-1}\right.$ of soil in observed in plots treated with $\mathrm{FYM}+$ non edible oil cakes + biofertilizers.

PSB and KSB: The count of phosphate solubilizing bacteria (PSB) and potassium solubilizing bacteria (KSB) significantly increased in treatments having organic manures and biofertilizers over the control treatment (Table 2). The maximum PSB count and KSB count $\left(63.00 \mathrm{cfu} \times 10^{5} \mathrm{~g}^{-1}\right.$ soil, $41.66 \mathrm{cfu} \times 10^{5} \mathrm{~g}^{-1}$ soil, $47.66 \mathrm{cfu} \times 10^{5} \mathrm{~g}^{-1}$ soil and $37.00 \mathrm{cfu} \times 10^{5} \mathrm{~g}^{-1}$ soil) were reported at panicle initiation than at harvesting stage which may be due to the availability of nutrients from the FYM and vermicompost for longer period of time to the bacteria. The findings were in the confirmation of the results of Iswandiet al. (2011) who reported that rice root exudates contain some organic compounds as a source of nutrition for microorganisms and encourages colonization in the population of Azospirillum spp. and PSB during flowering stage of rice crop.

Dehydrogenase activity: Dehydrogenase activity is affected by various treatments at the panicle initiation and harvesting stage of rice which are presented in the results. Microbial respiration is supposed to be highest in panicle initiation stage over harvesting stage of rice plant. The rice grows in the reciprocal and interactive ecosystem between soil-microorganism-rice and atmosphere, the rice development consequentially affect soil microorganism and soil enzymatic activities. In the present result the application of $\mathrm{T}_{5}\{(75 \% \mathrm{~N}$ (FYM) basal + $25 \% \mathrm{~N}(\mathrm{~V} / \mathrm{C})$ at 25 DAT + Azospirillum@ $5 \mathrm{~kg} \mathrm{ha}^{-1}+\mathrm{PSB} @ 5$ kg ha ${ }^{-1}+\mathrm{KSB} @ 5$ $\mathrm{kg} \mathrm{ha-1})\}$ significantly increase dehydrogenase activity by $81.62 \%, 10.80 \%, 24.86 \%, 15.66 \%$, $17.83 \%$ and $18.91 \%$ when compared with application of $T_{1}\{(R: D: F-40 \mathrm{~kg} \mathrm{~N}+30 \mathrm{~kg} \mathrm{P}+20 \mathrm{~kg}$
$\mathrm{K})\}, \mathrm{T}_{3}\{(100 \% \mathrm{~N}$ FYM $)$ as basal $\left.)\right\}, \mathrm{T}_{7}\{(100 \% \mathrm{~N}$ (GM) $\}, T_{8}\{(50 \% N(\mathrm{GM})+50 \% \mathrm{~N}(\mathrm{~V} / \mathrm{C})$ at 25 DAT)\}, $T_{9}\{(75 \% N(G M)+25 \% N(V / C)$ at 25 DAT + Azospirillum@ $5 \mathrm{~kg} \mathrm{ha}^{-1}+\mathrm{PSB} @ 5 \mathrm{~kg} \mathrm{ha}^{-1}$ + KSB @ $\left.\left.5 \mathrm{~kg} \mathrm{ha}^{-1}\right)\right\}$ and $\mathrm{T}_{10}\{(75 \% \mathrm{~N}(\mathrm{GM})+25$ $\% \mathrm{~N}(\mathrm{~V} / \mathrm{C})$ at 25 DAT + Panchagavya on foliar application)\} respectively. Similar trend follow at harvesting stage but at harvesting stage each and every inoculated species of VAM fungi having dehydrogenase activity is less than that of flowering stage inoculation. It might be due to the fact that organic compost and microbial inoculants itself can increase soil enzymatic activities (Caravaca et al., 2004). Addition of FYM @ $10 \mathrm{t} \mathrm{ha}^{-1}$ significantly increased the enzymatic activity in the soil. This increase might be due to manure application which promote biological and microbial activities and accelerated the breakdown of organic substances in the added manure, which is known to stimulate the dehydrogenase activity (Pedrazzini and Mckee, 1984).

Acid phosphatase: A trend similar to dehydrogenase activity was observed for the acid phosphatase activity during the study. The treatment $\mathrm{T}_{5}$ $\{(75 \% \mathrm{~N}(\mathrm{FYM})$ basal $+25 \% \mathrm{~N}$ (V/C) at $25 \mathrm{DAT}+$ Azospirillum@ $5 \mathrm{~kg} \mathrm{ha}^{-1}+\mathrm{PSB} @ 5 \mathrm{~kg} \mathrm{ha}^{-1}+\mathrm{KSB}$ @ $\left.\left.5 \mathrm{~kg} \mathrm{ha}^{-1}\right)\right\}$ resulted in significantly higher acid phosphatase activity with respect to other treatments. This treatment also gave similar trends at harvesting stage. At panicle initiation stage , application of $\mathrm{T}_{6}\{(75 \% \mathrm{~N}$ (FYM) as basal $+25 \% \mathrm{~N}(\mathrm{~V} /$ C) at 25 DAT + Panchagavya on foliar application)\} significantly increase dehydrogenase activity and with the applied treatments except application of $\mathrm{T}_{5}\{(75 \% \mathrm{~N}$ (FYM) basal $+25 \% \mathrm{~N}$ (V/C) at 25 DAT + Azospirillum@ $5 \mathrm{~kg} \mathrm{ha}^{-1}+\mathrm{PSB} @ 5 \mathrm{~kg} \mathrm{ha}^{-1}$ $\left.\left.+\mathrm{KSB} @ 5 \mathrm{~kg} \mathrm{ha}^{-1}\right)\right\}, \mathrm{T}_{4}\{(50 \% \mathrm{~N}(\mathrm{FYM})$ as basal $+50 \% \mathrm{~N}(\mathrm{~V} / \mathrm{C})$ at $25 \mathrm{DAT})\}$ and $\mathrm{T}_{2}\{(1 / 3 \mathrm{~N}$ ( FYM $)$ $+1 / 3 N(\mathrm{VC})+1 / 3 \mathrm{~N}(\mathrm{NC})\}$ at panicle stage.lt might be due to the more secretion of enzymes from the soil fungi. The similar results were obtained by Shwetha (2008) who found that the significantly higher microbial activity in the treatments given organic manures such as compost, vermicompost and green leaf manure with fermented organics viz., Beejamruth, Jeevamruth and Panchagavya over RDF (recommended dose of fertilizers), FYM and fermented organics alone.

Alkaline phosphatase activity: The results for alkaline phosphatase activity showed that the maximum activity for each and every applied treatment was recorded at panicle initiation stage than harvesting stage. The application with the treatment $\mathrm{T}_{5}\{(75 \% \mathrm{~N}$ (FYM) basal $+25 \% \mathrm{~N}(\mathrm{~V} / \mathrm{C})$ at 25 DAT + Azospirillum@ $5 \mathrm{~kg} \mathrm{ha}^{-1}+\mathrm{PSB} @ 5 \mathrm{~kg}$ $\left.\left.\mathrm{ha}^{-1}+\mathrm{KSB} @ 5 \mathrm{~kg} \mathrm{ha}^{-1}\right)\right\}$ and $\mathrm{T}_{6}\{(75 \% \mathrm{~N}$ (FYM) as basal $+25 \% \mathrm{~N}(\mathrm{~V} / \mathrm{C})$ at 25 DAT + Panchagavya on foliar application)\} given maximum Alkaline phosphatase activity at both the growth stages. The results are the confirmation of Singh, et al, 
2016. Soil enzymatic pool is mainly maintained by soil microorganisms. In addition to that other soil microflora, plant residues undergoing varying degree of decay also contributed to this pool (Krishnakumar et.al., 2005). Alkaline phosphatase activity of soil increased up to panicle initiation stage and declined afterwards. Rice crop produced higher amount of root exudation at initial stages of growth which enhanced microbial activity in crop and modified nutrient concentration in soil (Dotaniyaet.al 2014 and Singh et al. 2017).

Yield and yield parameters: The experimental findings showed that among applied organic treatments the maximum grain yield $\left(27.39 \mathrm{q} \mathrm{ha}^{-1}\right)$ and biological yield $\left(65.27 \mathrm{q} \mathrm{ha}^{-1}\right)$ was found in treatment $\mathrm{T}_{5}\{(75 \% \mathrm{~N}(\mathrm{FYM})$ basal $+25 \% \mathrm{~N}(\mathrm{~V} / \mathrm{C})$ at 25 DAT + Azospirillum@ $5 \mathrm{~kg} \mathrm{ha}^{-1}+$ PSB @ $5 \mathrm{~kg}$ $\left.\left.\mathrm{ha}^{-1}+\mathrm{KSB} @ 5 \mathrm{~kg} \mathrm{ha}^{-1}\right)\right\}$ and minimum (22.58 q ha $\left.^{-1}\right)$ was recorded in $\mathrm{T}_{7}\{(100 \% \mathrm{~N}(\mathrm{GM})\}$. Application of $\mathrm{T}_{5}\{(75 \% \mathrm{~N}$ (FYM) basal $+25 \% \mathrm{~N}(\mathrm{~V} / \mathrm{C})$ at 25 DAT + Azospirillum@ $5 \mathrm{~kg} \mathrm{ha}^{-1}+$ PSB @ 5 $\left.\left.\mathrm{kg} \mathrm{ha}^{-1}+\mathrm{KSB} @ 5 \mathrm{~kg} \mathrm{ha}^{-1}\right)\right\}$ significantly increased grain weight of paddy by $17.56 \%, 15.69 \%$, $15.91 \%$ over treatment $\mathrm{T}_{7}\left\{(100 \% \mathrm{~N}(\mathrm{GM})\}, \mathrm{T}_{9}\right.$ $\{(75 \% \mathrm{~N}(\mathrm{GM})+25 \% \mathrm{~N}(\mathrm{~V} / \mathrm{C})$ at $25 \mathrm{DAT}+$ Azospirillum@ $5 \mathrm{~kg} \mathrm{ha}^{-1}+\mathrm{PSB} @ 5 \mathrm{~kg} \mathrm{ha}^{-1}+\mathrm{KSB}$ @ $\left.\left.5 \mathrm{~kg} \mathrm{ha}^{-1}\right)\right\}$ and $\mathrm{T}_{10}\{(75 \% \mathrm{~N}(\mathrm{GM})+25 \% \mathrm{~N}$ (V/C) at 25 DAT + Panchagavya as foliar application )\}. However, the maximum straw yield (38.33) under the treatment $\mathrm{T}_{4}(50 \% \mathrm{~N}$ (FYM) as basal + $50 \% \mathrm{~N}$ (VC) at $25 \mathrm{DAT}$ ). This might be due to the more availability of nutrients for its uptake which leads to increase the plant biomass and its development. Similar findings observed by the Raghav and Shashi Kamal (2007). However there was no significant effect was found on straw yield by the applied treatment. The maximum straw yield was recorded under the application of treatment $\mathrm{T}_{4}$ $\{(50 \% N(F Y M)$ as basal $+50 \% N(\mathrm{~V} / \mathrm{C})$ at 25 DAT)\}. It may be because of vigorous growth of rice plants due to more availability of mineral to the crops. Several studies have revealed the positive effects of organic amendments and biofertilizers singly or in combination to increase plant nutrient availability, uptake and increase crop yield (Naderet al., 2008). Chaturvedi et al. (2008)also reported that organic amendments have a great effect on organic matter content and nutrient values, as well as improve the structure, water and air balance and microbiological activities of soils.

\section{Conclusion}

Organic management practices have the potential to upkeep the soil health as well as sustain the crop yield over a longer period of time. For scented rice varieties like Bhagalpur Katarni, which have relatively low nutrient requirement, a strategy for inclusion of completely organic treatments for crop production is worthwhile. After perusal of the results obtained in the study, it may be concluded that the application of $75 \% \mathrm{~N}$ (FYM) basal $+25 \% \mathrm{~N}(\mathrm{~V} / \mathrm{C})$ at $25 \mathrm{DAT}+$ Azospirillum @ $5 \mathrm{~kg}$ $\mathrm{ha}^{-1}+$ PSB @ $5 \mathrm{~kg} \mathrm{ha}^{-1}+\mathrm{KSB} @ 5 \mathrm{~kg} \mathrm{ha}^{-1}$ ) significantly increase the microbial population, enzymatic activity, available $\mathrm{N}, \mathrm{P}$ and $\mathrm{K}$ in soil over control treatment. This treatment also significantly increased grain yield when compared with T7 $\{(100 \% \mathrm{~N}(\mathrm{GM})\}$, T9 $\{(75 \% \mathrm{~N}(\mathrm{GM})+25 \% \mathrm{~N}(\mathrm{~V} /$ C) at 25 DAT + Azospirillum @ $5 \mathrm{~kg} \mathrm{ha} \mathrm{ha}^{-1}+$ PSB @ $\left.\left.5 \mathrm{~kg} \mathrm{ha}^{-1}+\mathrm{KSB} @ 5 \mathrm{~kg} \mathrm{ha}^{-1}\right)\right\}$ and T10 $\{(75 \% \mathrm{~N}(\mathrm{GM})+25 \% \mathrm{~N}(\mathrm{~V} / \mathrm{C})$ at $25 \mathrm{DAT}+$ Panchagavya on foliar application )\}. Since, agricultural sustainability is a priority in the modern day intensive agriculture, the positive effect of meticulously formulated treatments including organic amendments and microbial inoculants on the soil microbiological parameters and yield of scented Katarni variety of rice is encouraging.

\section{REFERENCES}

1. Ahemad, M. and Kibret, M. (2014). Mechanisms and applications of plant growth promoting rhizobacteria: Current perspective. Journal of King Saud UniversityScience, 26(1),1-20.

2. Bahadur, A., Singh, J., Singh, K.P., and Rai, M. (2006). Plant growth, yield and quality attributes of garden pea as influenced by organic amendments and biofertilizers. Indian J Hort., 63(4): 464-66.

3. Brar, A., Gosal, S.K. andWalia, S.S. (2017). Effect of biofertilizers and farm yard manure on microbial dynamics and soil health in maize (Zea mays L.) rhizosphere. Chemical Science Rev Letter, 6(23): 15241529.

4. Caravaca, F., Alguacil, M.M., Vassileva, M., Diaz, G. and Roldan, A. (2004). AM fungi inoculation and addition of microbially-treated dry olive cake-enhanced afforestation of a desertified Mediterranean site. Land Degrad. Dev., 15: 153-161.

5. Casida, L.E., Klein, D.A. and Santoro, T. (1964). Soil dehydrogenase activity. Soil Sci., 98:371-376.

6. Chaturvedi, S., Upreti, D.K., Tandon, D.K., Sharma, A. and. Dixit, A. (2008). Biowaste from tobacco industry as tailored organic fertilizer for improving yields and nutritional values of tomato crop. J. Environ. Biol., 29:759-763

7. Das, S.K. and Varma, A. (2011). Role of enzymes in maintaining soil health.-In: Shukla, G., Varma, A. (eds.) Soil Enzymology, Soil Biology 22, SpringerVerlag Berlin Heidelberg USA.

8. DACFW (2016). 'Agricultural Statistics at a glance 2016', pp. 87-89. , Department of Agriculture, Cooperation and Farmers Welfarehttp:// eands.dacnet.nic.in/PDF/Glance-2016.pdf

9. Dick, R.P. (1997). Soil acid and alkaline phosphatase activity as $\mathrm{pH}$ adjustment indicators. Soil Biol. Biochem., 32: 1915-19.

10.Dotaniya, M.L., Prasad, D., Meena, H.M., Jajoria, D.K., Narolia, G.P., Pingoliya, K.K., Meena, O.P., Kumar, K., Meena, B.P, Ram, A., Das, H., Chari, M.S. and Pal, S. (2013). Influence of phytosiderophore on iron and zinc uptake and rhizospheric microbial activity. Afr. J. Microbiol. Res., 7(51):57815788.

11.Gaur, A.C. (1991).Bulky organic manures and crop 
residues.In: Fertilizers, organic matter recyclable wastes and biofertilizer H.L.S Tandon, Fertilizer development and consultation Organisation, New Delhi.

12.Giraddi, R.S., Radha, D., Kale. andBiradar, D.P. (2001). Earthworms and organic matter recycling - an overview from Indian perspective. Karnataka J. Agric. Sci., 27 (3): (273-284).

13.Iswandi, A.O.P., Rupela.,T.M. and Thiyagarajan. (2011). A review of studies on SRI effects on beneficial organisms in rice soil rhizospheres. Paddy water Environ., 9, 53 -64.

14.Krishnakumar, S.,Saravanam, A.,Natrajan, S.K., Veerabadran, V. and Mani, S. (2005). Microbial population and enzymatic activity as influenced by organic farming. Res. J. Agric. and Biol. Sci., 1(1):85-88

15.Meena, B.P., Kumar, A., Lal, B., Sinha, N.K., Tiwari, P.K., Dotaniya, M.L., Jat, N.K. and Meena, V.D. (2015).Soil microbial, chemical properties and crop productivity as affected by organic manure application in popcorn (Zea mays L. var. everta). African Journalof Microbiology Research, Vol. 9(21), 14021408

16.Nader, R.H., Habashy., Amal, W.A. andRaafat, N.Z. (2008). Effect of organic and bio-fertilizers on phosphorus and some micronutrients availability in a calcareous soil. Journal of Agriculture and Biological Sciences, 4(5): 545-552.

17.Pedrazzini, F.R., McKee, K.L. (1984). Effect of flooding on activities of soil dehydrogenases in rice (Oryza sativa L.) roots. Soil Science and Plant Nutrition, 30: 359-366.

18.Raghav, M., Kamal, S. (2007). Organic farming technology for higher and eco-friendly cowpea production in Tarai region of Uttaranchal. Acta Horticulture, 752: 469-471.

19.Sarkar, S., Kundu, S.S. andGhorai, D. (2014). Validation of ancient liquid organics- Panchagabhya and Kunapajala as plant growth promoters. Indian Journal of Traditional Knowledge, 13(2): 398-403.

20.Shwetha, B.N.(2008). Effect of nutrient management through the organics in soybean - wheat cropping system. M. Sc. (Agri.) Thesis, Univ. Agric. Sci. Dharwad.

21.Singh, M.,Beura, K., Pradhan, A.K. and Kumar, N. (2016).Efficacy of Micronutrient application on potential of Bradyrhizobium In enhancement of growth and yield of Soybean. The Bioscan, 11(1): 309-314.

22.Singh, M.,Yadav, S., Kumar, N., Ojha, M.D. and Kumar, V. (2017). Effect of Organic Manures and NPK on Nodulation, Microbial Biomass Carbon and Yield of Soybeam. Environment \& Ecology, 35 (3): 1605 1609.

23.Snedecor, G.W. andCochron, W.G. (1971). Statistical methods. $6^{\text {th }}$ edition. Oxford and IBH Pub. Co., New Delhi. 593 pp.

24.Subbha, R.N.S. (1986). Rhizobium and root nodulation In: soil microorganisms and plant growth. $2^{\text {nd }} \mathrm{Ed}$. New Delhi, Oxford IBH. 123: 183 pp.

25.Tabatabai, M.A. andBremner,J.M .(1969). Use of pnitrophenyl phosphate for assay of phosphatase activity. Soil Bio Biochem., 1: 301-307.

26.Upadhayay, R.G., Sharma, S. andDrawal, N.S (1999). Effect of Rhizobium inoculation and graded level of Pea on the growth and yield of greengram. Legume Res., 22: 277-279.

27.Upadhyay, V.B., Jain, V., Vishwakarma, S.K. and Kumar, A.K. (2011). Production potential, soil health water productivity and economic of rice (Oryza sativa) based cropping system under different nutrients sources. Indian J. Agron., 56(4): 311-316.

28.Vasanthi, D. andKurriaraswamy, K. (1999). Efficacy of vermicompostto improve soil fertility and rice yield. J. Indian Soc. Soil Sci., 47: 268-272.

29.Vaxevanidou, K., Christou, C., Kremmydas, G.F., Georgakopoulos, D.G. and Papassiopi, N. (2015). Role of indigenous arsenate and iron (III) Respiring microorganisms in controlling the mobilization of arsenic in a Contaminated soil Sample. Bull. Environ. Cont. Toxicol., 94(3):282-288.

30.Verma, D. K., and Srivastav, P. P. (2017). Proximate Composition, Mineral Content and Fatty Acids Analyses of Aromatic and Non-Aromatic Indian Rice. Rice Science, 24(1):21-31. 